\title{
Novel thermophilic bacteria producing nitrile-degrading enzymes
}

\author{
Rebecca Cramp, Martin Gilmour and Don A. Cowan
}

Author for correspondence: Don A. Cowan. Tel: +44 171 3877050. Fax: +44 1713807193 e-mail: don.cowan@ucl.ac.uk

Department of Biochemistry and Molecular Biology, University College London, Gower Street, London WC1E 6BT, UK
The first known report of the isolation of thermophilic bacteria which produce nitrile-degrading enzymes is presented. One of the strains isolated was studied in detail. Strain Dac521, classified as Bacillus pallidus, was capable of growth on acetonitrile, benzonitrile, propionitrile, acetamide, benzamide and propionamide as the sole carbon and nitrogen source in minimal nutrient media. The strain produced separate aliphatic-nitrile (e.g. acetonitrile)- and aromatic-nitrile (e.g. benzonitrile)-degrading activities. Acetonitrile-degrading activity was produced constitutively and enzyme production was not enhanced by the addition of substrate. Under conditions where benzonitrile was the sole carbon and nitrogen source in minimal nutrient media, acetonitrile-degrading enzyme activity was completely inhibited and benzonitrile-degrading activity was induced. Growth on substrates as sole carbon and nitrogen sources, together with the substrate specificity of cell-free extracts, suggested that acetonitrile and benzonitrile degradation may have occurred via nitrile hydratase and nitrilase pathways, respectively. Both the acetonitrile- and benzonitrile-degrading enzyme systems were significantly more thermostable in whole-cell preparations and cell-free extracts compared to their mesophilic counterparts.

Keywords: Bacillus pallidus, thermophilic, nitrilase, nitrile hydratase

\section{INTRODUCTION}

Nitriles (i.e. organo-cyanides of the general formula $\mathrm{RC} \equiv \mathrm{N}$ ) are common constituents of plants (Kobayashi et al., 1989) and occur as intermediates of microbial metabolism (Kobayashi et al., 1993a). Their hydrolysis is catalysed by nitrile-degrading enzymes which occur in a wide variety of plants (Thimann \& Mahadevan, 1964), mesophilic bacteria [e.g. Brevibacterium (Arnaud et al., 1977), Arthrobacter (Asano et al., 1982), Nocardia (Harper, 1985), Klebsiella (Stalker et al., 1988), Corynebacterium (Li et al., 1992) and Rbodococcus (Langdahl et al., 1996)] and fungi [e.g. Fusarium solani (Harper, 1977), Myrothecium verrucaria (Maier-Greiner et al., 1991) and Fusarium lateritium (Cluness et al., 1993)].

Nitrile hydrolysis occurs by two major enzymic pathways (Faber, 1992; Mahadevan \& Thimann, 1964). One pathway (1) involves the sequential hydrolysis of the nitrile molecule to its corresponding carboxylic acid and ammonia via an amide intermediate, catalysed by two different enzymes: a hydratase and an amidase. The other (2) is the direct hydrolysis by a nitrilase to the corresponding carboxylic acid and ammonia.

$$
\begin{aligned}
& \mathrm{R}-\mathrm{CN}+\mathrm{H}_{2} \mathrm{O} \stackrel{\substack{\text { Nitrile } \\
\text { nydratase }}}{\rightarrow} \mathrm{R}-\mathrm{CONH}_{2} \stackrel{\substack{\text { Amidase } \\
+\mathrm{H}_{2} \mathrm{O}}}{\rightarrow} \mathrm{R}-\mathrm{COOH}+\mathrm{NH}_{3} \\
& \mathrm{R}-\mathrm{CN}+2 \mathrm{H}_{2} \mathrm{O} \stackrel{\text { Nitrilase }}{\rightarrow} \mathrm{R}-\mathrm{COOH}+\mathrm{NH}_{3}
\end{aligned}
$$

These enzymes are of particular interest as many nitriles and their hydrolysed derivatives are used in commercial processes including paper manufacture (Hwang \& Chang, 1989) and waste treatment (Nazly et al., 1983) or to produce commercially viable compounds such as acrylamide (Kobayashi et al., 1993b), antibiotics (Jallageas et al., 1980), anti-inflammatory agents (Gilligan et al., 1993) and herbicides (Bianchi et al., 1991). Chemical hydrolysis of nitriles often involves relatively harsh conditions which precludes the use of nitriles carrying sensitive functionalities. In addition, unwanted byproducts, including large amounts of salt, are often formed. Biotransformation of nitriles, using nitriledegrading enzymes (Bengis-Garber \& Gutman, 1988; Bhalla et al., 1992), overcomes these problems and may offer the additional advantage of stereospecificity (Bianchi et al., 1991; Kakeya et al., 1991; Layh et al., 1992). However, application of these enzymes in in- 
dustry is still limited, in part due to the intrinsic thermal instability (Nagasawa et al., 1993) of the known mesophilic enzymes. Here we report the isolation of thermophilic nitrile-degrading bacterial strains, together with evidence that the intracellular nitrile-degrading enzymes have substantially higher thermal stability than known mesophilic homologues.

\section{METHODS}

Chemicals. Acetonitrile and acrylamide were obtained from $\mathrm{BDH}$. Acrylonitrile, benzamide, benzonitrile, isovaleronitrile, propionamide and propionitrile were obtained from Aldrich. Dithiothreitol and acetamide were obtained from SigmaAldrich. Nutrient broth no. 2 and purified agar were obtained from Oxoid. API 20E and API 50CH analytical profile index kits and API $50 \mathrm{CHB}$ media were obtained from BioMérieux. Working concentrations of benzonitrile were prepared in $10 \%(\mathrm{v} / \mathrm{v})$ methanol.

Microbial culture. Cultures were grown on minimal nutrient plates at $50^{\circ} \mathrm{C}$ for up to $7 \mathrm{~d}$. The minimal nutrient plates contained: $\left(\mathrm{NH}_{4}\right)_{2} \mathrm{SO}_{4}, 1.60 \mathrm{~g} \mathrm{l}^{-1} ; \mathrm{MgSO}_{4}, 0.25 \mathrm{~g} \mathrm{l}^{-1} ; \mathrm{CaCl}_{2}$, $0.05 \mathrm{~g} \mathrm{l}^{-1} ; \mathrm{KH}_{2} \mathrm{PO}_{4}, 0.50 \mathrm{~g} \mathrm{l}^{-1}$ (pH 7.5); purified agar, $20.00 \mathrm{~g} \mathrm{l}^{-1}$; and $0 \cdot 10 \%(\mathrm{v} / \mathrm{v})$ nitrile. Five different nitriles were used separately as the sole carbon source: acetonitrile, benzonitrile, isovaleronitrile, propionitrile and acrylonitrile.

Pure isolates were grown in liquid minimal media using each of the five nitriles separately as the sole nitrogen source. The minimal media contained: $\mathrm{MgSO}_{4}, 0.25 \mathrm{~g} \mathrm{l}^{-1} ; \mathrm{CaCl}_{2}$, $0.05 \mathrm{~g} \mathrm{l}^{-1} ; \mathrm{KH}_{2} \mathrm{PO}_{4}, 0.50 \mathrm{~g} \mathrm{l}^{-1} ; \mathrm{CoCl}_{2}, 0.35 \mathrm{~g} \mathrm{l}^{-1} ; 0.50 \%(\mathrm{v} / \mathrm{v})$ glycerol; and $0.05 \%(\mathrm{v} / \mathrm{v})$ nitrile.

Isolate Dac521 was routinely grown in the following minimal medium: $\mathrm{KH}_{2} \mathrm{PO}_{4}, 2 \mathrm{~g} \mathrm{l}^{-1} ; \mathrm{NaCl}, 1 \mathrm{gl}^{-1} ; \mathrm{MgSO}_{4}, 0 \cdot 2 \mathrm{gl}^{-1}$; thiamin, $0.4 \mathrm{mg} \mathrm{l}^{-1}$; biotin, $2 \mu \mathrm{g} \mathrm{l}^{-1}$; inositol, $2 \mathrm{mg} \mathrm{l}^{-1}$; $\mathrm{FeSO}_{4}$, $10 \mathrm{mg} \mathrm{l}^{-1}$; $\left(\mathrm{NH}_{4}\right)_{2} \mathrm{SO}_{4}, 1.32 \mathrm{~g} \mathrm{l}^{-1}$; sodium succinate, $5 \cdot 4 \mathrm{~g} \mathrm{l}^{-1}$; $\mathrm{pH} 7 \cdot 2$. Nitriles $(20 \mathrm{mM})$ were substituted for succinate and/or $\left(\mathrm{NH}_{4}\right)_{2} \mathrm{SO}_{4}$ as the sole carbon and/or nitrogen source, respectively, except where otherwise stated. Cultures were grown at $50{ }^{\circ} \mathrm{C}$ in $250 \mathrm{ml}$ flasks containing $50 \mathrm{ml}$ media or in 21 flasks containing $500 \mathrm{ml}$ media, with a reciprocation rate of 300 r.p.m.

Strain characterization. Standard oxidase tests, spore staining, Gram staining, catalase tests and motility tests (Collins et al., 1995) were performed using fresh cultures of strain Dac521.

Analytical profile index (API) tests $50 \mathrm{CH}$ and $20 \mathrm{E}$ (Logan \& Berkeley, 1984) were used to aid identification. API $50 \mathrm{CHB}$ defined medium and distilled water were used to inoculate the test kits, respectively. Both $50 \mathrm{CH}$ and 20E API strips were incubated at $50^{\circ} \mathrm{C}$ and the experiments were performed in triplicate according to the protocol set out in the API guidelines.

For hybridization studies, chromosomal DNA was extracted from test strains using the method of White et al. (1993). DNA from strain Dac521 was labelled with $\left[{ }^{32} \mathrm{P}\right] \mathrm{dCTP}$ by the random primer method and unincorporated nucleotides were removed using NAP-10 columns. Probe DNA was hybridized to target DNA from 10 thermophilic Bacillus species $(B$. thermoglucosidasius, $B$. thermodenitrificans, $B$. caldovelox, B. stearothermophilus, B. pallidus, B. caldolyticus, B. kaustophilus, B. smithii, B. thermocloacae and B. thermo- catenulatus; kindly provided by Professor R. Sharp, CAMR, Porton Down, UK) immobilized on nitrocellulose filters using a slot blot system (Schleicher \& Schuel) at $50^{\circ} \mathrm{C}$ under nonstringent conditions. Percentage homology was calculated from the radioactivity of the hybrids relative to nonhomologous and homologous controls using a Joyce-Loebl chromoscan 3 densitometer.

Maximum growth rate determination. The same initial starter culture $(10 \%, v / v)$, grown at $50^{\circ} \mathrm{C}$, was used to inoculate all flasks. Growth $\left(\mathrm{OD}_{600}\right.$ versus time) was monitored at each temperature at least in triplicate and an aliquot of each culture was spread on a nutrient agar plate to check culture purity. All growth experiments were performed at a reciprocation rate of 300 r.p.m. Actual rates were determined using the formula $\ln x_{t}=\ln x_{\mathrm{o}}+\mu_{t}$, where $x_{t}=$ biomass concentration after time interval $t \mathrm{~h}, x_{\mathrm{o}}=$ original biomass concentration, $\mu=$ specific growth rate $\left(\mathrm{h}^{-1}\right), t=$ time $(\mathrm{h})$ and $\mu_{\max }=$ growth rate during exponential phase.

Preparation of whole-cell suspensions and cell-free extracts. Cultures were harvested by centrifugation at $6000 \mathrm{~g}$ for $15 \mathrm{~min}$, then washed with $50 \mathrm{mM}$ potassium phosphate buffer containing $1 \mathrm{mM}$ dithiothreitol and $20 \%(\mathrm{v} / \mathrm{v})$ glycerol (pH 7.2), and re-centrifuged for $15 \mathrm{~min}$ at $27000 \mathrm{~g}$. The pellet was then resuspended in a minimal volume of $50 \mathrm{mM}$ potassium phosphate buffer containing $1 \mathrm{mM}$ dithiothreitol and $20 \%(\mathrm{v} / \mathrm{v})$ glycerol $(\mathrm{pH} 7 \cdot 2)$. Cell suspensions were sonicated in an ice-bath using an MSE Soniprep 150 (five bursts of $10 \mathrm{~s}$ duration, $10 \mu$ amplitude, with $20 \mathrm{~s}$ intervals). Disrupted cells were centrifuged at $27000 \mathrm{~g}$ for $15 \mathrm{~min}$ and the supernatant was retained.

Protein determination. Protein concentrations were determined using the Bio-Rad Bradford protein determination kit with bovine serum albumin (fraction V; Sigma) as the protein standard.

Nitrile-degrading enzyme assay. Nitrile-degrading enzyme activity was assayed by measuring the production of ammonia by a modification of the phenol/hypochlorite method of Fawcett \& Scott (1960). In determining nitrile hydratase activity by ammonia release, the specific activity of intracellular amidase was consistently found to be higher than that of the nitrile hydratase for the substrates tested. In light of these relative rates, we concluded that the nitrile to amide conversion was rate limiting and that measurement of ammonia released was a quantitative measurement of nitrile hydratase activity.

The following reagents were used for ammonia detection. Reagent A contained $0.59 \mathrm{M}$ phenol and $1 \mathrm{mM}$ sodium nitroprusside. Reagent B contained $110 \mathrm{mM}$ sodium hypochlorite and $2 \mathrm{M}$ sodium hydroxide. The standard assay was performed in duplicate at $50^{\circ} \mathrm{C}$ in a reaction comprising, unless otherwise stated, $300-x \mu \mathrm{l} 50 \mathrm{mM}$ potassium phosphate buffer containing $1 \mathrm{mM}$ dithiothreitol and $20 \%(\mathrm{v} / \mathrm{v})$ glycerol (pH 7.2), $x \mu \mathrm{l}$ extract or whole-cell suspension and $5 \mu \mathrm{l} 4 \cdot 2 \mathrm{M}$ acetonitrile or $1.2 \mathrm{M}$ benzonitrile. Samples were incubated at $50^{\circ} \mathrm{C}$ for $15 \mathrm{~min}$. The cell-free extract reaction was quenched by addition of $100 \mu \mathrm{l}$ of the assay mixture to $350 \mu$ l reagent $B$ followed by rapid addition of $350 \mu \mathrm{l}$ reagent $A$ with vigorous mixing and incubation at $50{ }^{\circ} \mathrm{C}$ for $15 \mathrm{~min}$. The whole-cell reaction was quenched by centrifugation at $2080 \mathrm{~g}$ for $3 \mathrm{~min}$ after incubation, followed by addition of $100 \mu \mathrm{l}$ of the supernatant to $350 \mu \mathrm{l}$ reagent $\mathrm{B}$, followed by rapid addition of $350 \mu \mathrm{l}$ reagent $\mathrm{A}$ with vigorous mixing and incubation at $50^{\circ} \mathrm{C}$ for $15 \mathrm{~min}$. The $A_{600}$ was then measured in a Cecil (model CE1020) spectrophotometer. One unit of acetonitrile- or 
benzonitrile-degrading enzyme activity was defined as the amount of enzyme capable of releasing $1 \mu \mathrm{mol} \mathrm{ammonia} \mathrm{min}^{-1}$ under standard reaction conditions $\left(\mathrm{pH} 7 \cdot 2,50^{\circ} \mathrm{C}, 70 \mathrm{mM}\right.$ acetonitrile or $20 \mathrm{mM}$ benzonitrile as substrate).

Temperature stability of enzyme activities. Aliquots of enzyme preparation, in $50 \mathrm{mM}$ potassium phosphate buffer containing $1 \mathrm{mM}$ dithiothreitol and $20 \%$ (v/v) glycerol ( $\mathrm{pH} 7 \cdot 2$ ), were incubated at specified temperatures. At specific time intervals, samples were removed and placed on ice. Activity in all samples was subsequently determined using the standard enzyme assay procedure at $50^{\circ} \mathrm{C}$.

\section{RESULTS AND DISCUSSION}

\section{Isolation strategies}

Sediment samples collected from thermal sites in New Zealand (Tokaanu, Whakarewarewa, Waimangu and Taupo) were stored at $-20^{\circ} \mathrm{C}$. Primary isolations were performed by spreading aqueous suspensions of these samples on minimal nutrient medium plates containing various nitriles as the sole carbon source. After incubation at $50^{\circ} \mathrm{C}$ for $3-4 \mathrm{~d}$, colonies were picked and restreaked onto the same minimal nutrient medium plates. The plating cycle was repeated until pure cultures were obtained. Nitrile degradation was tentatively confirmed by incubating duplicate cultures on minimal nutrient medium plates supplemented and not supplemented with nitrile as the sole carbon source under otherwise identical conditions. The appearance of more rapid growth in the presence of the nitrile was taken as putative evidence for the presence of nitrile-degrading enzymes.

\section{Nitrile-degrading isolates}

Twenty-eight thermophilic isolates were examined for their ability to grow at $50^{\circ} \mathrm{C}$ in liquid minimal nutrient media with nitriles (acetonitrile, benzonitrile, isovaleronitrile, propionitrile or acrylonitrile) as the sole carbon or nitrogen source. Growth on acetonitrile, propionitrile and isovaleronitrile gave higher growth rates and biomass yields than growth on benzonitrile or acrylonitrile. A single strain (designated Dac521) which showed higher nitrile-degrading enzyme activity during growth in liquid minimal nitrile media relative to other isolates was selected for further characterization.

\section{Morphology and taxonomy}

Isolate Dac521, a Gram-positive, sporulating, nonmotile, rod-shaped organism $(2.0 \times 0.7 \mu \mathrm{m})$ which grew between 35 and $70^{\circ} \mathrm{C}$ on solid media and up to $73^{\circ} \mathrm{C}$ in liquid media, was identified as a thermophilic Bacillus species using the API $50 \mathrm{CH}$ and $20 \mathrm{E}$ identification test strips (Logan \& Berkeley, 1984). On nutrient agar plates, Dac521 colonies were of non-uniform size, circular form, convex elevation, with an entire margin and a yellow/grey colour. The organism was catalaseand oxidase-positive and fermented glucose, fructose and saccharose. Using DNA-DNA hybridization, strain Dac521 showed $87 \%$ homology to B. pallidus and less
Table 1. DNA hybridization results

Percentage DNA:DNA homology of ${ }^{32} \mathrm{P}$-labelled Dac521 DNA against membrane-filter-bound test DNA. Percentage homology was calculated from the radioactivity of the hybrids relative to non-homologous and homologous controls. Data are mean values of quadruplicate experiments with standard deviations in parentheses.

\begin{tabular}{|lc|}
\hline Test species & Homology $(\%)$ \\
\hline B. thermoglucosidasius & $14(4 \cdot 8)$ \\
B. thermodenitrificans & $15(4 \cdot 2)$ \\
B. caldovelox & $2(1 \cdot 9)$ \\
B. pallidus & $87(17 \cdot 7)$ \\
B. stearothermophilus & $3(2 \cdot 4)$ \\
B. caldolyticus & $2(1 \cdot 9)$ \\
B. kaustophilus & $3(2 \cdot 0)$ \\
B. smithii & $6(3 \cdot 5)$ \\
B. thermocloacae & $4(2 \cdot 3)$ \\
B. thermocatenulatus & $3(3 \cdot 2)$ \\
Isolate Dac521 & $100(-)$ \\
\hline
\end{tabular}

than $15 \%$ homology to all other type strains tested (Table 1). According to White et al. (1993), this level of homology is strongly indicative of species designation and morphological and physiological characteristics were similar to those reported for the B. pallidus H14 type strain (White et al., 1993; Scholz et al., 1987).

\section{Temperature optimum}

The optimum growth temperature for $B$. pallidus Dac521 in nutrient broth was $50^{\circ} \mathrm{C}$ (maximum growth rate, $\left.\mu_{\max },=1.00 \pm 0.01 \mathrm{~h}^{-1}\right) . \mu_{\max }$ fell to less than $10 \%$ of this value at $40^{\circ} \mathrm{C}$. No growth was detected at $74^{\circ} \mathrm{C}$ or above. These results appear consistent with the description of $B$. pallidus Dac521 as a moderate thermophile. The $\mu_{\max }$ of cultures grown in minimal nutrient media with acetonitrile or benzonitrile as the sole carbon and nitrogen source at $50^{\circ} \mathrm{C}$ was $0.28 \pm 0.01 \mathrm{~h}^{-1}$ and $0.06 \pm 0.01 \mathrm{~h}^{-1}$, respectively, approximately $28 \%$ and $6 \%$ of the growth rates seen in nutrient broth at the same temperature.

\section{Growth and activity profiles}

B. pallidus Dac521 expressed aliphatic-nitrile- and amide-degrading activities when grown in nutrient broth (Fig. 1). Cell-free extracts from exponential and early stationary phase cultures degraded acetonitrile, propionitrile, acrylonitrile and the corresponding amides but no degradation of benzonitrile, isovaleronitrile or benzamide was detected. Nitrile-degrading enzyme activity was detectable from early exponential to mid stationary phase and the specific activity was highest at the transition from exponential to stationary phase. The specific activity was not enhanced by the addition of nitriles to the growth medium at the time of inoculation or at various times during culture growth (data not 


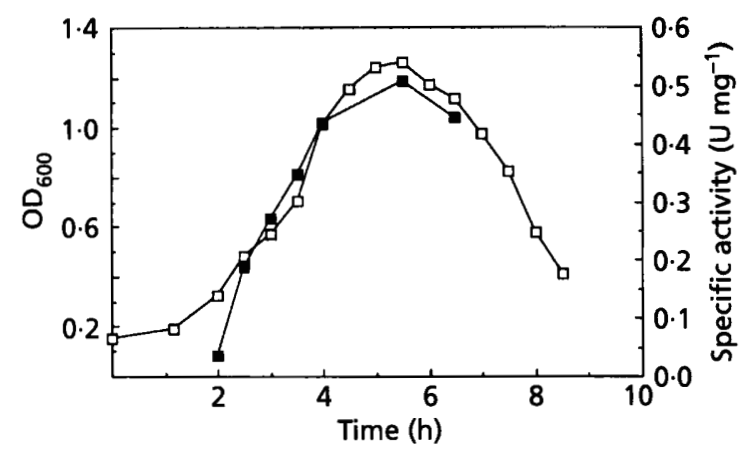

Fig. 1. Growth on nutrient broth and acetonitrile-degrading enzyme activity profiles for B. pallidus Dac521. Culture growth was monitored by the $O_{600}(\square)$. At specific time-points, aliquots of the culture were removed, sonicated and acetonitrile-degrading activity and protein concentration were determined. Specific activity $(\square)$ is expressed as $\mu \mathrm{mol}$ ammonia produced $\mathrm{min}^{-1}(\mathrm{mg} \text { protein })^{-1}\left(\mathrm{U} \mathrm{mg}^{-1}\right)$.

shown). Under the culture conditions used, B. pallidus Dac521 had a short stationary phase followed by a rapid decrease in $\mathrm{OD}_{600}$ with a concurrent decrease in detectable acetonitrile-degrading activity, consistent with a reduction or cessation of expression of the relevant gene(s) and induction of a specific degradation pathway (Morihara, 1974; Atalo \& Gashe, 1993).

Under optimal conditions, B. pallidus Dac521 produced $1.3 \mathrm{U}$ acetonitrile-degrading activity (mg dry wt cells) ${ }^{-1}$ compared to $0 \cdot 1 \mathrm{U} \mathrm{mg}^{-1}$ for Arthrobacter sp. J-1 (Asano et al., 1982).

\section{Acetonitrile-degrading activity}

DEAE-Sephacel ion-exchange chromatography (data not shown) of cell-free extracts of $B$. pallidus Dac521 grown in nutrient broth resulted in baseline separation of nitrile hydratase and amidase activities, capable of degradation of acetonitrile to acetamide and acetamide to acetic acid, respectively. As no other acetonitriledegrading enzymes were detected in repeated chromatographic separations, we propose that acetonitrile degradation occurs via a hydratase-amidase pathway. The nitrile hydratase was shown to act on acetonitrile, propionitrile and acrylonitrile while the amidase hydrolysed the corresponding amides.

Microbial enzymes responsible for the catabolism of carbon compounds are often repressed by glucose and other hexoses (Toda, 1981; Tourneix et al., 1986; Magasanik, 1961; Zimmermann \& Scheel, 1977). Similarly, microbial enzymes intervening in nitrogen compound metabolism can be repressed by the ammonium ion (Yoch \& Whiting, 1986). To investigate the possible occurrence of enzyme induction and/or repression, B. pallidus Dac521 was grown with a variety of carbon and nitrogen sources (Table 2).

Cell-free extracts of $B$. pallidus Dac521 grown in minimal nutrient media with succinate, pyruvate or glucose as the sole carbon source and ammonium sulphate as the sole nitrogen source showed similar acetonitrile-degrading specific activities to that found in nutrient broth cultures, suggesting that catabolite repression or fixed nitrogen repression of aliphatic nitrile hydratase-amidase gene expression is not significant under the experimental conditions used. Other nitriledegrading cultures (e.g. Rhodococcus rhodochrous J1; Nagasawa et al., 1988) have also been shown to be insensitive to catabolite repression from carbon sources such as glucose and glycerol.

The acetonitrile-degrading activity of $B$. pallidus Dac521 was not enhanced by the addition of acetonitrile to nutrient broth or to minimal media with glucose or succinate as sole carbon source (Table 2). Conversely, when acetonitrile was supplied as the sole carbon and/or nitrogen source, the enzyme specific activities decreased to between $2 \%$ and $26 \%$ of those observed in nutrient broth. These results may be interpreted to imply that the aliphatic nitrile substrate suppresses expression of the acetonitrile-degrading enzyme gene, but may also suggest that expression is co-ordinately linked to cell growth parameters.

\section{Aromatic-nitrile-degrading activity}

When $B$. pallidus Dac521 was grown in minimal nutrient media with benzonitrile as the sole carbon and nitrogen source (Fig. 2), no acetonitrile-degrading activity was detectable but a distinct benzonitrile-degrading enzyme activity was observed. After a sequence of DEAESephacel ion-exchange, phenyl-Sepharose hydrophobic interaction, and Superdex 200 and Superose 12 gel filtration chromatography steps, a single peak of benzonitrile-degrading activity was routinely eluted (data not shown). Using ammonia release assays, benzamide was not found to be a substrate over a wide range of concentrations (data not shown). Together these findings suggest strongly that benzonitrile degradation was via a nitrilase enzyme system.

Benzonitrilase specific activity increased during exponential phase but rapidly decreased during stationary phase, suggesting rapid 'switch-off' of benzonitrilase gene expression coupled with an active degradation mechanism. Maximum specific yields of benzonitrilase activity were approximately $0.2 \mathrm{U}$ benzonitrilase activity (1 culture $)^{-1}$ compared to $5.0 \mathrm{U} \mathrm{l}^{-1}$ for $R$. rhodochrous J1 (Nagasawa et al., 1988).

Although benzonitrile-degrading (benzonitrilase) activity was not detected until mid-late exponential growth phase (Fig. 2), acetonitrile degradation was not detected at any time during the growth phase. Furthermore, only benzonitrile-degrading activity was detectable in cultures grown in minimal media supplemented with both benzonitrile and acetonitrile (Table 2). These results are consistent with either total repression of 'acetonitrilase' gene expression (by benzonitrile) or quantitative inhibition of 'acetonitrilase' activity. However, when benzamide was substituted for benzonitrile in the 
Table 2. Effect of carbon and nitrogen source on specific activities of acetonitrile-degrading enzymes

A $10 \%(\mathrm{v} / \mathrm{v})$ inoculum of $B$. pallidus Dac521 grown in nutrient broth to an $\mathrm{OD}_{600}$ of 1.2 was used to inoculate all flasks. $B$. pallidus Dac521 was grown in $50 \mathrm{ml}$ vols minimal nutrient media in $250 \mathrm{ml}$ flasks at $50^{\circ} \mathrm{C}$ with a reciprocation rate of $300 \mathrm{r}$.p.m. Cultures were grown to early stationary phase before harvesting, sonication and determination of enzyme activity (acetonitrile/benzonitrile as substrate) and protein concentration. Data are mean values of triplicate or quadruplicate experiments \pm standard errors. 0 , No activity detected.

\begin{tabular}{|c|c|c|}
\hline Carbon and nitrogen source & $\begin{array}{l}\text { Acetonitrile degradation } \\
\qquad\left(\mathrm{U} \mathrm{mg}^{-1}\right)\end{array}$ & $\begin{array}{c}\text { Benzonitrile degradation } \\
\left(\mathrm{U} \mathrm{mg}^{-1}\right)\end{array}$ \\
\hline Nutrient broth & $0.45 \pm 0.02$ & 0 \\
\hline $20 \mathrm{mM}$ succinate $+20 \mathrm{mM}$ ammonium sulphate & $0.40 \pm 0.02$ & 0 \\
\hline $20 \mathrm{mM}$ pyruvate $+20 \mathrm{mM}$ ammonium sulphate & $0.59 \pm 0.17$ & 0 \\
\hline $20 \mathrm{mM}$ glucose $+20 \mathrm{mM}$ ammonium sulphate & $0.42 \pm 0.06$ & 0 \\
\hline $20 \mathrm{mM}$ acetonitrile $+20 \mathrm{mM}$ glucose & $0.01 \pm 0.001$ & 0 \\
\hline $20 \mathrm{mM}$ acetonitrile $+20 \mathrm{mM}$ succinate & $0.05 \pm 0.01$ & 0 \\
\hline $20 \mathrm{mM}$ acetonitrile $+20 \mathrm{mM}$ ammonium sulphate & $0 \cdot 12 \pm 0 \cdot 02$ & 0 \\
\hline $20 \mathrm{mM}$ acetonitrile & $0.08 \pm 0.04$ & 0 \\
\hline $20 \mathrm{mM}$ benzonitrile & 0 & $0 \cdot 13 \pm 0 \cdot 002$ \\
\hline $5 \mathrm{mM}$ acetonitrile $+15 \mathrm{mM}$ benzonitrile & 0 & $0 \cdot 15 \pm 0.01$ \\
\hline $10 \mathrm{mM}$ acetonitrile $+10 \mathrm{mM}$ benzonitrile & 0 & $0 \cdot 18 \pm 0 \cdot 02$ \\
\hline $15 \mathrm{mM}$ acetonitrile $+5 \mathrm{mM}$ benzonitrile & 0 & $0 \cdot 10 \pm 0 \cdot 002$ \\
\hline
\end{tabular}

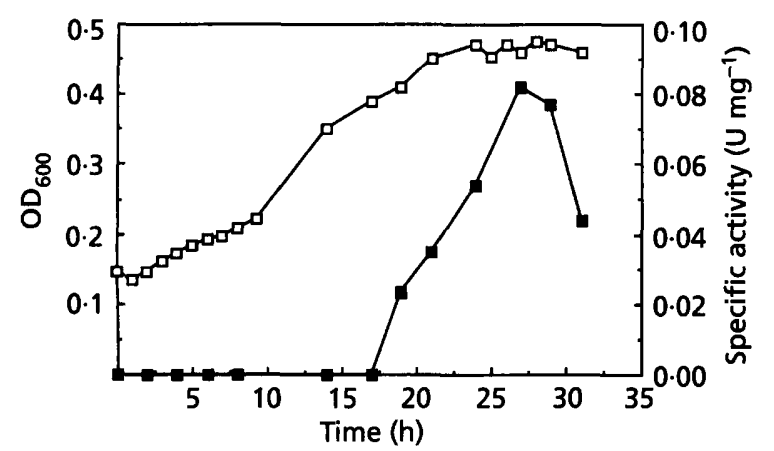

Fig. 2. Growth on minimal medium with benzonitrile as sole carbon source and benzonitrile-degrading enzyme activity profiles for B. pallidus Dac521. Culture growth was monitored by the $\mathrm{OD}_{600}(\square)$. At specific time-points, aliquots of the culture were removed, sonicated and benzonitrile-degrading activity and protein concentration were determined. Specific activity $(\mathbb{D})$ is expressed as $\mu \mathrm{mol}$ ammonia produced $\mathrm{min}^{-1}$ (mg protein $)^{-1}\left(\mathrm{U} \mathrm{mg}^{-1}\right)$.

growth medium under otherwise identical growth conditions, acetonitrile-degrading activity was detectable, suggesting that the aliphatic nitrile hydratase activity was suppressed, whether at the gene or enzyme level, by benzonitrile and not by the aromatic moiety alone. To further test the mode of 'inactivation', whole cells or cell-free extracts of $B$. pallidus Dac521 containing acetonitrile-degrading enzyme activity were incubated with $5 \mathrm{mM}$ benzonitrile for $5 \mathrm{~min}$ at $50^{\circ} \mathrm{C}$. Subsequent assays failed to detect 'acetonitrilase' activity. Since 'acetonitrilase' activity was observed to be completely stable under similar conditions $\left(50^{\circ} \mathrm{C}, 5 \mathrm{~min}\right)$, we conclude that inhibition of enzymic activity is the probable cause. Attempts to recover activity by centrifuging the benzonitrile-treated samples and resuspending the cells in fresh buffer containing no benzonitrile (each sample washed in triplicate) were unsuccessful (both positive and negative controls were as expected). Inhibition was therefore concluded to be effectively irreversible.

Similar patterns of enzyme activity, attributed to differential control of gene expression, have been reported previously for a number of mesophilic micro-organisms, including Nocardia rhodochrous (Collins \& Knowles, 1983), Arthrobacter sp. strain J-1 (Asano et al., 1982; Bandyopadhyay et al., 1986), $R$. rhodochrous J1 (Kobayashi et al., 1992) and Fusarium solani (Harper, 1977; Shimizu \& Taguchi, 1969). However, both the results of our in vivo growth studies and in vitro inhibition assays strongly support the contention that the aliphaticspecific nitrile hydratase activity in $B$. pallidus Dac521 is inhibited rapidly and essentially irreversibly by benzonitrile.

\section{Amidase expression}

B. pallidus Dac521 appeared to express at least two distinct amidases. Growth in nutrient broth with benzonitrile or acetonitrile as the sole carbon and nitrogen source induced expression of an amidase which degraded acetamide but not benzamide. Conversely, growth with benzamide resulted in expression of a benzamide-specific amidase. In an analogous manner, $R$. rhodochrous $\mathrm{J} 1$ expresses two distinct amidases in a mutually exclusive and inducer-dependent fashion (Kobayashi et al., 1993b). 


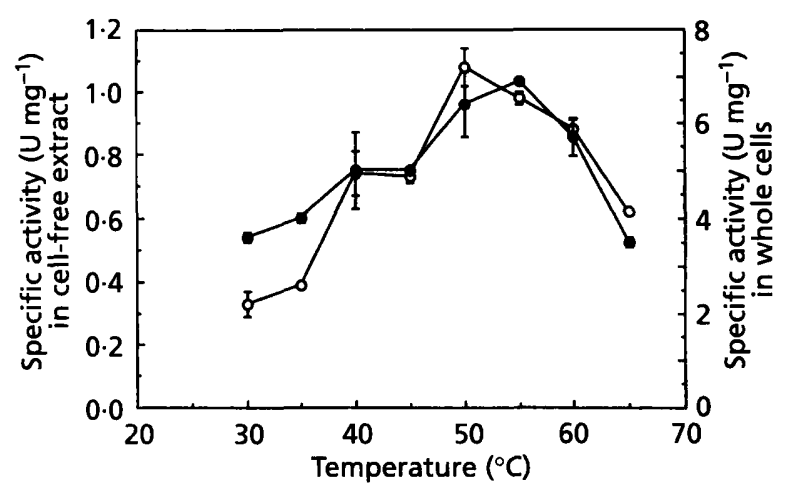

Fig. 3. Temperature-activity profiles of B. pallidus Dac521 acetonitrile-degrading enzymes. The rate of acetonitrile $(20 \mathrm{mM})$ degradation at a range of temperatures was determined in $50 \mathrm{mM}$ potassium phosphate buffer containing $1 \mathrm{mM}$ dithiothreitol and $20 \%(\mathrm{v} / \mathrm{v})$ glycerol (pH 7.2). Whole-cell $(O)$ and cell-free extract $(O)$ specific activities are expressed as $\mu \mathrm{mol}$ ammonia produced $\mathrm{min}^{-1}(\mathrm{mg} \text { protein })^{-1}\left(\mathrm{U} \mathrm{mg}^{-1}\right)$.

\section{Temperature-activity relationships}

The temperature dependence of acetonitrile degradation by $B$. pallidus Dac521 whole-cell suspensions and cellfree extracts (Fig. 3) showed maximum rates at 55 and $50{ }^{\circ} \mathrm{C}$, respectively. It is notable that the $Q_{10}$ values for the two reaction systems are significantly different (estimated to be approximately $1 \cdot 3$ and $1 \cdot 9$, respectively).

\section{Stability}

The thermal stabilities of the acetonitrile- and benzonitrile-degrading enzyme systems were determined for both suspensions of whole cells and cell-free extracts
(Table 3). The greater apparent stability of both the acetonitrile- and benzonitrile-degrading enzyme systems in whole cells (compared with buffered cell-free extracts) may reflect either the release of compartmentalized degradation enzymes or a sensitivity to alterations in solution properties ( $\mathrm{pH}, \mathrm{l}$, solutes, etc.). The substantial decrease in half-life between 50 and $60^{\circ} \mathrm{C}$ ( 25 -fold for cell-free extracts) for the acetonitrile-degrading activity suggests that this temperature range encompasses the putative $T_{m}$ of one of the two enzymes involved in aliphatic nitrile degradation.

Biotransformations using mesophilic nitrile hydratases and nitrilases are typically carried out at low temperatures $\left(0-10^{\circ} \mathrm{C}\right)$ due to the instability of the enzymes (Hwang \& Chang, 1989; Gilligan et al., 1993). For example, Brevibacterium R312 and R. rhodochrous J1 nitrile hydratases were completely inactivated after a $10 \mathrm{~min}$ incubation at $30^{\circ} \mathrm{C}$ (Nagasawa et al., 1993). For purposes of comparison, assuming first order decay of activity to zero over $10 \mathrm{~min}$, the nitrile hydratases of Brevibacterium $\mathrm{R} 312$ and $R$. rhodochrous $\mathrm{J} 1$ may have half-lives of 1-3 min at this temperature. In comparison, cell-free extracts of $B$. pallidus Dac521 had activity halflives at $30^{\circ} \mathrm{C}$ of $40 \mathrm{~h}$ and $2.5 \mathrm{~d}$ for the nitrile hydratase and benzonitrilase, respectively (Table 3 ). Thus we estimate that $B$. pallidus Dac521 nitrile hydratase and benzonitrilase are, respectively, approximately 1500 fold and 2500 -fold more stable at $30^{\circ} \mathrm{C}$ than the Brevibacterium R312 and R. rhodochrous J1 enzymes.

Immobilized Brevibacterium $\mathrm{CH} 1$ cells (used industrially for acrylamide production) had a half-life of activity of $7.5 \mathrm{~h}$ at $35^{\circ} \mathrm{C}$ (Hwang \& Chang, 1989). In comparison, non-immobilized $B$. pallidus Dac521 cells had activity half-lives of $5 \mathrm{~d}$ at $30^{\circ} \mathrm{C}$ and $66.5 \mathrm{~h}$ at $40^{\circ} \mathrm{C}$.

Table 3. Half-lives of acetonitrile- and benzonitrile-degrading enzyme activity in whole-cell suspensions and cell-free extracts

Aliquots of enzyme, in $50 \mathrm{mM}$ potassium phosphate buffer containing $1 \mathrm{mM}$ dithiothreitol and $20 \%$ $(\mathrm{v} / \mathrm{v})$ glycerol $(\mathrm{pH} 7 \cdot 2$ ), were incubated at the specified temperatures. At specific time intervals, samples were removed and placed on ice. Activity in all samples was subsequently determined using the standard enzyme assay procedure at $50^{\circ} \mathrm{C}$. Data are mean values of triplicate experiments \pm standard errors. ND, Not determined.

\begin{tabular}{|c|c|c|c|c|}
\hline \multirow[t]{2}{*}{$\begin{array}{l}\text { Temp. } \\
\left({ }^{\circ} \mathrm{C}\right)\end{array}$} & \multicolumn{2}{|c|}{$\begin{array}{c}\text { Stability }\left(t_{1}\right) \text { of acetonitrile- } \\
\text { degrading activity }\end{array}$} & \multicolumn{2}{|c|}{$\begin{array}{c}\text { Stability }\left(t_{\frac{1}{2}}\right) \text { of benzonitrile- } \\
\text { degrading activity }\end{array}$} \\
\hline & Cell-free extract & Whole cells & Cell-free extract & Whole cells \\
\hline 4 & ND & $43.5 \pm 0.5 \mathrm{~d}$ & ND & ND \\
\hline 22 & ND & $25 \cdot 0 \pm 0.0 \mathrm{~d}$ & ND & ND \\
\hline 30 & $40 \cdot 0 \pm 0 \cdot 1 \mathrm{~h}$ & $5 \cdot 0 \pm 0 \cdot 2 \mathrm{~d}$ & $2 \cdot 5 \pm 0.1 \mathrm{~d}$ & $7 \cdot 0 \pm 0 \cdot 1 \mathrm{~d}$ \\
\hline 40 & $15 \cdot 0 \pm 0.0 \mathrm{~h}$ & $66.5 \pm 0.5 \mathrm{~h}$ & $1 \cdot 0 \pm 0.1 \mathrm{~d}$ & $3.5 \pm 0.1 \mathrm{~d}$ \\
\hline 50 & $3 \cdot 1 \pm 0 \cdot 1 \mathrm{~h}$ & $4.5 \pm 0.0 \mathrm{~h}$ & $3 \cdot 8 \pm 0.2 \mathrm{~h}$ & $6.5 \pm 0.2 \mathrm{~h}$ \\
\hline 55 & $1 \cdot 9 \pm 0.1 \mathrm{~h}$ & ND & ND & ND \\
\hline 60 & $7 \cdot 3 \pm 0 \cdot 1 \mathrm{~min}$ & $8 \cdot 2 \pm 0.1 \mathrm{~min}$ & $14.9 \pm 1 \cdot 1 \mathrm{~min}$ & $34 \cdot 0 \pm 2 \cdot 0 \mathrm{~min}$ \\
\hline 70 & ND & ND & $<1.0 \mathrm{~min}$ & $<1.0 \mathrm{~min}$ \\
\hline
\end{tabular}


On the basis of thermal stability alone, these results suggest that the $B$. pallidus Dac521 nitrile hydratase and nitrilase may have significant industrial advantages over their mesophilic counterparts.

\section{ACKNOWLEDGEMENTS}

The authors wish to thank the Biotechnology and Biological Sciences Research Council for financial support.

\section{REFERENCES}

Arnaud, A., Gazly, P. \& Jallageas, J. C. (1977). Etude de l'acetonitrilase d'une souche de Brevibacterium. Agric Biol Chem 41 , 2183-2191.

Asano, Y., Fujishiro, K., Tany, Y. \& Yamada, H. (1982). Aliphatic nitrile hydratase from Arthrobacter sp. J-1: purification and characterization. Agric Biol Chem 46, 1165-1174.

Atalo, K. \& Gashe, B. A. (1993). Protease production by a thermophilic Bacillus species (P-001A) which degrades various kinds of fibrous proteins. Biotechnol Lett 15, 1151-1156.

Bandyopadhyay, A. K., Nagasawa, T., Asano, Y., Fujishiro, K., Tani, Y. \& Yamada, H. (1986). Purification and characterisation of benzonitrilases from Arthrobacter sp. strain J-1. Appl Environ Microbiol 51, 302-306.

Bengis-Garber, C. \& Gutman, A. (1988). Bacteria in organic synthesis: selective conversion of 1,3 dicyanobenzene into 3 cyanobenzoic acid. Tetrahedron Lett 29, 2589-2590.

Bhalla, T., Miura, A. \& Wakamoto, A. (1992). Asymmetric hydrolysis of $\alpha$-aminonitriles to optically active amino acids by a nitrilase of Rhodococcus rhodochrous $\mathrm{Pa}-34$. Appl Microbiol Biotechnol 37, 184-190.

Bianchi, D., Bosetti, A., Cesti, P., Franzosi, G. \& Spezia, S. (1991). Stereoselective microbial hydrolysis of 2-aryloxypropionitriles. Biotechnol Lett 13, 241-244.

Cluness, M. D., Turner, P. D., Clements, E., Brown, D. T. \& O’Reilly, C. (1993). Purification and properties of cyanide hydratase from Fusarium lateritium and analysis of the corresponding chy 1 gene. J Gen Microbiol 139, 1807-1815.

Collins, P. A. \& Knowles, C. J. (1983). The utilization of nitriles and amides by Nocardia rbodochrous. J Gen Microbiol 129, 711-718.

Collins, C. H., Lyne, P. M. \& Grange, J. M. (editors) (1995). Identification methods. In Microbiological Methods, pp. 103-110. Oxford: Butterworth-Heinmann.

Faber, K. (editor) (1992). Biocatalytic applications. In Biotransformations in Organic Chemistry, pp. 114-115. Berlin: Springer.

Fawcett, J. K. \& Scott, J. E. (1960). A rapid and precise method for the determination of urea. J Clin Pathol 13, 156-159.

Gilligan, T., Yamada, H. \& Nagasawa, T. (1993). Production of S(+)-2-phenylpropionic acid from (R,S)-2-phenylpropionitrile by the combination of nitrile hydratase and stereoselective amidase in Rhodococcus equi TG328. Appl Microbiol Biotechnol 39, 720-725.

Harper, D. B. (1977). Enzymology of C-N cleavage by Fusarium solani. Biochem J 167, 685-692.

Harper, D. B. (1985). Characterization of a nitrilase from Nocardia sp. N.C.I.B. 11215, using p-hydroxybenzonitrile as sole carbon source. Int J Biochem 17, 677-683.

Hwang, J. \& Chang, H. (1989). Biotransformation of acrylonitrile to acrylamide using immobilised whole cells of Brevibacterium $\mathrm{CH} 1$ in a recycle fed batch reactor. Biotechnol Bioeng 34, 380-386.

Jallageas, J. C., Arnaud, A. \& Galzy, P. (1980). Bioconversions of nitriles and their applications. Adv Biochem Eng 14, 1-32.

Kakeya, H., Sakai, N., Sugai, T. \& Ohta, H. (1991). Microbial hydrolysis as a potent method for the preparation of optically active nitriles, amides and carboxylic acids. Tetrabedron Lett 32, 1343-1346.

Kobayashi, M., Nagasawa, T. \& Yamada, H. (1989). Nitrilase of Rhodococcus rhodochrous $\mathrm{J} 1$ : purification and characterisation. Eur J Biochem 182, 349-356.

Kobayashi, M., Komeda, H. \& Yanaka, N. (1992). Nitrilase from Rhodococcus rhodochrous J1. J Biol Chem 267, 20746-20751.

Kobayashi, M., Izui, H., Nagasawa, T. \& Yamada, H. (1993a). Nitrilase in biosynthesis of plant hormone indole-3-acetic acid from indole-3-acetonitrile: cloning of the Alcaligenes gene and site directed mutagenesis of cysteine residues. Proc Natl Acad Sci USA 90, 247-251.

Kobayashi, M., Komeda, H., Nagasawa, T., Yamada, H. \& Shimizu, S. (1993b). Occurrence of amidase in the industrial microbe, Rhodococcus rhodochrous J1. Biosci Biotechnol Biochem 57, 1949-1950.

Langdahl, B. B., Bisp, P. \& Ingvorsen, K. (1996). Nitrile hydrolysis by Rhodococcus erythropolis BL1, an acetonitrile-tolerant strain isolated from a marine sediment. Microbiology 142, 145-154.

Layh, N., Stolz, A., Forster, S., Effenberger, F. \& Knackmuss, H. (1992). Enantioselective hydrolysis of O-acetylmandelonitrile to O-acetylmandelic acid by bacterial nitrilases. Arch Microbiol 158, 405-411.

Li, W., Zhang, Y. \& Yang, H. (1992). Formation and purification of nitrile hydratase from Corynebacterium pseudodiphtheriticum ZBB-41. Appl Biochem Biotechnol 36, 171-181.

Logan, N. A. \& Berkeley, R. C. W. (1984). Identification of Bacillus strains using the API system. J Gen Microbiol 130, 1871-1882.

Magasanik, B. (1961). Catabolite repression. Cold Spring Harbor Symp Quant Biol 26, 249-256.

Mahadevan, S. \& Thimann, K. (1964). Nitrilase: substrate specificity and possible mode of action. Arch Biochem Biophys $107,62-68$.

Maier-Greiner, U. H., Obermaier-Skrobranek, B. M. M., Estermaier, L. M. \& 9 other authors (1991). Isolation and properties of a nitrile hydratase from the soil fungus Myrothecium verrucaria that is highly specific for the fertiliser cyanamide and cloning of its gene. Proc Natl Acad Sci USA 88, 4260-4264.

Morihara, K. (1974). Comparative specificity of microbial proteinases. Adv Enzymol 41, 179-243.

Nagasawa, T., Kobayashi, M. \& Yamada, H. (1988). Optimum culture conditions for the production of benzonitrilase by Rhodococcus rhodochrous J1. Arch Microbiol 150, 89-94.

Nagasawa, T., Shimizu, S. \& Yamada, H. (1993). The superiority of the third generation catalyst $R$ hodococcus rhodochrous J1 nitrile hydratase for industrial production of acrylamide. Appl Microbiol Biotechnol 40, 189-195.

Nazly, N., Knowles, C. J., Beardsmore, A. J., Naylor, W. T. \& Corcoran, E. G. (1983). Detoxification of cyanide by immobilised fungi. J Chem Technol Biotechnol 33B, 119-126.

Scholz, T., Demharter, W., Hensel, R. \& Kandler, O. (1987). Bacillus pallidus sp. nov., a new thermophilic species from sewage. Syst Appl Microbiol 9, 91-96.

Shimizu, T. \& Taguchi, H. (1969). Microbial treatment of industrial wastes containing cyanide. J Ferment Technol 47, 639-643. 
Stalker, D. M., Malyi, L. D. \& McBride, K. E. (1988). Purification and properties of a nitrilase specific for the herbicide bromoxynil and corresponding nucleotide sequence analysis of the $b x n$ gene. $J$ Biol Chem 263, 6310-6314.

Thimann, K. V. \& Mahadevan, S. (1964). Nitrilase: occurrence, preparation and general properties of the enzyme. Arch Biochem Biophys 105, 133-141.

Toda, K. (1981). Induction and repression of enzymes in microbial culture. J Chem Technol Biotechnol 31, 775-790.

Tourneix, D., Thiery, A., Maestracci, M., Arnaud, A. \& Galzy, P. (1986). Regulation of nitrile hydratase synthesis in a Brevibacterium species. Antonie Leeuwenboek 52, 173-182.

White, D., Sharp, R. J. \& Priest, F. G. (1993). A polyphasic taxonomic study of thermophilic bacilli from a wide geographical area. Antonie Leeuwenhoek 64, 357-386.

Yoch, D. C. \& Whiting, G. J. (1986). Evidence for $\mathrm{NH}_{4}^{+}$switch-off regulation of nitrogenase activity by bacteria in salt marsh sediments and roots of the grass Spartina alterniflora. Appl Environ Microbiol 51, 143-149.

Zimmermann, F. K. \& Scheel, I. (1977). Mutants of S. cerevisiae resistant to carbon catabolite repression. Mol Gen Genet 154, $75-82$.

Received 13 September 1996; revised 13 February 1997; accepted 17 March 1997. 